\title{
Growth hormone doping: a review
}

This article was published in the following Dove Press journal:

Open Access Journal of Sports Medicine

26 July $201 \mathrm{I}$

Number of times this article has been viewed

\section{loulietta Erotokritou- Mulligan \\ Richard IG Holt \\ Peter H Sönksen}

Developmental Origins of Health and Disease Division, University of Southampton School of Medicine, The Institute of Developmental Science, Southampton General Hospital, Southampton, UK
Correspondence: Peter H Sönksen The Institute of Developmental Sciences (IDS Building), MP887, University of Southampton, Southampton General Hospital,Tremona Road, Southampton SOI6 6YD, UK

Tel +4402380795006

Email phsonksen@aol.com
Abstract: The use of growth hormone $(\mathrm{GH})$ as a performance enhancing substance was first promoted in lay publications, long before scientists fully acknowledged its benefits. It is thought athletes currently use $\mathrm{GH}$ to enhance their athletic performance and to accelerate the healing of sporting injuries. Over recent years, a number of high profile athletes have admitted to using GH. To date, there is only limited and weak evidence for its beneficial effects on performance. Nevertheless the "hype" around its effectiveness and the lack of a foolproof detection methodology that will detect its abuse longer than 24 hours after the last injection has encouraged its widespread use. This article reviews the current evidence of the ergogenic effects of GH along with the risks associated with its use. The review also examines methodologies, both currently available and in development for detecting its abuse.

Keywords: performance enhancing substance, $\mathrm{GH}$, doping in sport, detection methods

\section{Introduction}

Growth hormone $(\mathrm{GH})$ is a naturally occurring peptide hormone produced by the anterior pituitary gland. It plays a major role in maintaining body composition, well-being, physical performance, and cardiovascular health in adults as well as children. These properties have led to its abuse by professional sportsmen and women wishing to improve their athletic performance. Despite its apparent widespread use, until recently there was little scientific evidence to support its use as a performance enhancing agent. Recent studies, however, have suggested that GH increases both strength and sprint capacity.

This article reviews the current evidence of the ergogenic effects of GH along with the risks associated with its use. The review also examines methodologies, both currently available and in development for detecting its abuse.

PubMed and Google Scholar were searched for relevant use of the terms "growth hormone" and "abuse". Where further references were found within these articles, they were downloaded. This review also draws from the clinical and research experience of the three authors who have been working together within the GH-2004 project to develop a test for GH abuse for the last 9 years. Prior to that PHS was a member of the International Olympic Committee Medical Commission and led the GH-2000 project, the aim of which was to develop a test for GH abuse in time for the Sydney Olympic Games.

\section{The evolution of growth hormone into a performance enhancing agent}

The end of the 19th century saw the birth of organotherapy following a series of groundbreaking and controversial experiments undertaken by Charles Édouard 
Brown-Sequard, a renowned physiologist and neurologist. Brown-Sequard's unique experiments led the way for significant advancements in the field of endocrinology. His findings were presented for the first time to the Society of Biology in Paris in 1891, reporting significant restoration of his own strength following a 3-week program of self-injection of "first blood of the testicular veins; secondly semen; and thirdly juice from a testicle ... from a dog or a guinea pig". ${ }^{1}$ Although many now believe that his findings may have been the result of a placebo effect, it is well accepted that the idea of hormone replacement and organotherapy was conceived as a result.

Brown-Sequard was the first to propose that "internal secretions ought to exist in animal tissues and that disease probably resulted from their lack". Brown-Sequard's research saw the beginning of a series of experiments throughout the Western world, investigating this method for rejuvenation as well as a treatment for various diseases.

It is unsurprising that this research was identified as an area that should be investigated as a means of improving athletic performance, and in 1894 Oskar Zoth, and Fritz Pregl were the first to consider this by assessing the effect of testicular extracts on muscular strength. With hindsight it is unlikely these testicular extracts contributed positively to the performance of athletes; however, Zoth and Pregl, while investigating the effect on athletic performance, provided the grounds where such research could be furthered.

Shortly after, in 1909, Harvey Cushing identified the etiology of acromegaly for the first time through a partial hypophysectomy, which also enabled him to suggest the potential treatment. This was the first time the role of pituitary hormones was considered and opened the way to our understanding of the role of $\mathrm{GH}$ on normal physiology.

GH was first extracted and purified from the human pituitary glands in $1945 .^{2} \mathrm{GH}$ administration was shown to promote growth in hypopituitary animals and children with hypopituitarism who subsequently demonstrated a dramatic improvement in growth. ${ }^{3}$ In adults, the beneficial effects of GH administration were first observed in 1962, when GH was noted to increase vigour, ambition and sense of well-being in a woman with adult hypopituitarism. ${ }^{4}$

Cadaveric growth hormone was the only source of the hormone until 1987 when the first recombinant version (methionyl human GH) became available. Pituitaryderived GH was subsequently found to be a source for the prion-induced Creutzfelt-Jacob disease and was withdrawn from the marketplace in $1985 ;{ }^{5}$ however, supplies of pituitary-derived GH continue to be available on the black market to this day.

It is not known exactly when GH was first used as a performance enhancing substance but the first published evidence we have is in The Underground Steroid Handbook by Daniel Duchaine, which appeared with a limited circulation in California in early $1982 .{ }^{6}$ The cyclostyled newsletter encouraged athletes to use $\mathrm{GH}$ to enhance their performance. Specifically, Duchaine stated in his newsletter: "Wow, is this great stuff! It is the best for permanent muscle gains ... People who use it can expect to gain 30 to 40 pounds of muscle in 10 weeks". ${ }^{6}$ Duchaine was known in the bodybuilding community as the "steroid guru" and was responsible for the development of many doping trends. Through experimentation on himself and other bodybuilders he was coaching, he advised athletes on the best substances and combinations for optimal performance.

Duchaine later retracted this statement, as he could not find any scientific studies that supported his claims. In his later book published in 1993 "Ultimate muscle mass" he stated that "I'd guess that almost $90 \%$ of all athletes taking STH [growth hormone] got no anabolic results from it (this includes at least two Mr Olympia competitors)" ${ }^{6,7}$ However, the damage had already been done by that time as the use of $\mathrm{GH}$ was proliferating among the doping world. History shows that his earlier comments were the more accurate as we now know that $\mathrm{GH}$ is a potent anabolic agent particularly when combined with testosterone. ${ }^{8}$

\section{Evidence of $\mathbf{G H}$ abuse in sport}

There are no official incidence figures to show how common GH usage is amongst athletes or how popular it is in sporting circles owing to its illicit nature. One of the most wellknown recorded examples of $\mathrm{GH}$ misuse involved Ben Johnson who admitted taking GH to boost his performance. Following Ben Johnson's admission, Justice Charles Dubin conducted one of the most searching investigations into the abuse of drugs in sports. During these hearings, the Canadian sprinter Angella Issanjenko also admitted using GH along with other drugs. According to the 900-page inquiry report, ${ }^{9}$ it was concluded that the tight regulations limiting GH use had not prevented it from becoming widely available to athletes. Dubin also added in his conclusion that it appeared there was a growing trend of $\mathrm{GH}$ use as a performance enhancing agent. 
In 1989 the International Olympic Committee (IOC) included GH in its prohibited substance list, as part of a new doping class of "peptide hormones and analogs" despite the lack of a legitimate test for human (h)GH. ${ }^{10}$ However, this did not seem to deter $\mathrm{GH}$ misuse as a performance-enhancing substance. For many athletes it became the new drug of choice, ${ }^{11}$ with some athletes calling the 1996 Olympics in Atlanta, USA, the "hGH games". 12

Over the years, many accusations have been made against athletes claiming that they have been abusing GH. However, without a reliable detection method, the World Anti-Doping Agency (WADA) and the IOC have been unable to prove this. National Football League players, such as Bill Romanowski, and baseball players, Barry Bonds, Gary Sheffield, and Jason Giambi, are amongst some of the sportsmen accused of taking GH in the controversial book Game of Shadows, which was written following the undercover investigations of two San Francisco reporters. ${ }^{13}$

One of the most infamous pieces of evidence of GH abuse came after the raid on the Bay Area Laboratory Co-Operative's (BALCO) headquarters on September 3, 2003. Victor Conte, the owner of BALCO, claimed that he had supplied GH to many high-profile American athletes including Tim Montgomery and Marion Jones. Marion Jones, five-time Olympic medal winner, admitted in 2007 to using performance enhancing drugs including GH. She was later sentenced to a 6-month jail sentence for falsely denying administering performanceenhancing substances. Tim Montgomery allegedly admitted to taking GH before a US Federal grand jury and later faced a 2-year ban for doping offences. Conte was imprisoned for 4 months for his role in the scandal. ${ }^{13}$

$\mathrm{GH}$ is readily available to purchase over the internet, a factor that has led to its use becoming more widespread. As part of an investigation for the British Broadcasting Corporation, laboratory analysis of a batch of $\mathrm{GH}$ obtained over the internet by four-time Olympic gold medalist, Matthew Pinsent, confirmed that the purported GH was indeed of very high purity. ${ }^{14}$

Although Pfizer Pharmaceuticals was fined US\$ 35 million for promoting $\mathrm{hGH}$ as an anti-aging and performance enhancing agent in $2007,{ }^{15}$ their advertisement is likely to have encouraged its abuse in the sporting arena. It is now illegal to prescribe, possess, or use GH for any unlicensed purpose in the US.

\section{Physiological influences on the GH/insulin growth factor axis}

To understand why athletes believe GH is a potent ergogenic aid, it is useful to review the physiology of GH. GH is secreted from the anterior pituitary gland under the regulation of the hypothalamic hormones, somatostatin, growth hormone releasing hormone (GHRH), and ghrelin. It is secreted in pulses and is rapidly cleared leading to highly variable circulating concentrations.

\section{Gender}

Over a 24 -hour period, young women secrete $50 \%$ more $\mathrm{GH}$ than young men. In addition, in premenopausal women, GH production varies according to the menstrual cycle, approximately doubling in the late follicular phase compared with the early follicular and mid-luteal phases. This variation is thought to be related to changes in gonadal steroid production as GH pulse amplitude is positively correlated with serum estradiol and negatively correlated with serum progesterone ${ }^{16}$ After a glucose load, plasma GH levels are normally suppressed to greater extent in young men and young women in the early follicular phase of their menstrual cycle.

\section{Nutrition}

Body composition has a significant effect on GH production. Obese individuals have reduced mean GH concentrations, associated with decreased pulsatile GH secretion and a shorter GH half-life. The peak response of GH secretion to GHRH is reduced in obese subjects and this is reversible with fasting or weight loss. A possible explanation for this is related to obesity induced hyperinsulinemia, which may inhibit GH secretion, through enhanced negative-feedback inhibition by insulin growth factor-I (IGF-I).$^{17}$ The concentration of ghrelin, which acts to increase GH secretion, is reduced in obese people, but it is unclear whether this mediates the reduced GH secretion observed in visceral obesity. ${ }^{18}$

People with anorexia nervosa, by contrast, demonstrate increased basal and GHRH-stimulated GH release and elevated ghrelin levels. People with anorexia nervosa have low circulating IGF-I and IGFBP-3 concentration as a result of low hepatic insulin activity and can be viewed as developing a state of functional GH resistance. In healthy individuals, fasting increases GH production through an increase in GH pulse frequency and amplitude whereas re-feeding rapidly has the opposite effect suppressing fasting-enhanced $\mathrm{GH}$ secretion.

\section{Age}

$\mathrm{GH}$ is secreted at a low level in early childhood. Secretion increases gradually during childhood but increases three-fold during puberty, reaching a peak during late puberty. After early adulthood, GH production starts to decline at a rate of approximately $14 \%$ per decade of adult life. ${ }^{19}$ 
It is thought that the decline in GH secretion that occurs with increasing age is associated with a reduction in $\mathrm{GH}$ storage. ${ }^{20}$ In parallel with the age related fall in $\mathrm{GH}$ secretion, serum IGF-I and insulin-like growth factor-binding protein-3 (IGFBP-3) concentration also decline, ${ }^{21}$ though the concentration of the latter falls to a lesser degree than IGF-I and GH secretion. ${ }^{22}$ In elderly individuals, the correlation between $\mathrm{GH}$ secretion and IGF-I and IGFBP-3 is less marked, suggesting that $\mathrm{GH}$ becomes less important in determining circulating IGF-I concentration with advancing age and instead other factors such as nutritional state, frailty, and chronic disease may play a greater role.

\section{Exercise}

Physical exercise plays an important role in the regulation of the GH-IGF-I axis ${ }^{20}$ increasing GH secretion. The GH response to exercise is dependent on the duration and intensity of the exercise, the fitness of the exercising subject, and other environmental factors such as the ambient temperature during exercise $^{23}$ and body composition. ${ }^{24}$

The effect of exercise is greater in young women than postmenopausal women and men of any age. Furthermore, the same study showed that age diminishes the GH response to exercise and abolishes the young-adult gender difference. ${ }^{25}$ The duration of exercise needed to induce GH secretion after physical exercise is inversely related to the exercise intensity. ${ }^{26}$

Anaerobic exercise is more stimulatory to $\mathrm{GH}$ release than continuous aerobic exercise, even if duration and workload are kept the same for the two types of exercise. ${ }^{27}$ Although exercise is a powerful stimulus to $\mathrm{GH}$ release, the $\mathrm{GH}$ response to exercise is blunted in older and obese individuals. ${ }^{24}$ This suggests that higher exercise intensities may be necessary to stimulate GH release in obese subjects to levels achieved in normal weight adults.

\section{Benefits of $\mathbf{G H}$ in athletic performance}

Many athletes believe that GH will improve their athletic performance; however, to date there is only a small amount of published evidence to support such claims in amateur young adult recreational athletes..$^{8,28}$ No published evidence exists in elite athletes. The majority of evidence showing the effect of $\mathrm{GH}$ administration comes from studies of $\mathrm{GH}$ replacement in GH-deficient adults.

The use of randomized clinical trials is currently accepted as the gold standard methodology for assessing the efficacy of medical products. It is difficult, however, to undertake such
$\mathrm{GH}$ administration studies to demonstrate reliably whether GH increases muscle bulk and strength in the athletic population for ethical and legal reasons. Furthermore, it is probably the case that athletes use a 'trial of one' paradigm to learn the benefits of GH, as they know their performance precisely and by trying different diets, training regimens, and/or drugs they can deduce which ones improve performance by a level that they know exceeds their 'within-subject' variability.

Athletes abuse GH in combination with anabolic steroids and other performance enhancing substances, in varying concentrations during differing training and dietary regimens. Any change in performance could result from the synergistic action of these different interventions. These complex regimens are impossible to replicate in a single research trial, and therefore it seems likely that athletes are the ones who are best placed to address the question whether $\mathrm{GH}$ is performance enhancing. This approach was certainly used by the former East German coaches when athletes experimented with anabolic steroids. ${ }^{29}$

\section{Effect of growth hormone administration Body composition}

Growth hormone has a key role in regulating body composition. An important property of $\mathrm{GH}$ is its potent lipolytic effect. ${ }^{30,31} \mathrm{GH}$ administration in people with $\mathrm{GH}$ deficiency reduces body fat mass and increases lean body mass significantly. ${ }^{32}$ In a recent meta-analysis study it was concluded that $\mathrm{GH}$ administration in healthy athletes increase lean body mass by an average of $1.8 \mathrm{~kg} .{ }^{33}$

GH increases lipolysis directly by reducing the action of a number of lipogenic enzymes ${ }^{31}$ and indirectly by increasing the production of other lipolytic hormones, such as catecholamines and glucagon, and by increasing adipocyte adrenergic receptors expression. Overall these effects lead to increased body fat utilization. ${ }^{34}$

\section{Muscle protein synthesis and strength}

One of the best appreciated effects of GH is its effect on muscle anabolism. Reduced muscle mass and protein synthesis is seen when GH and IGF-I production are reduced. ${ }^{35-39}$ GH induces glucose and amino acid uptake, and stimulates protein synthesis, possibly using the energy derived from its lipolytic activity. ${ }^{31}$ By contrast GH has little effect on protein degradation. Instead insulin and to a lesser extent IGF-I inhibit protein degradation and this may explain why some athletes abuse insulin and GH together. The effects of GH on protein are mediated both indirectly via IGF-I and directly. ${ }^{30}$ 
The anabolic effect on protein and catabolic effect on fat leads to increased muscle mass at the expense of fat mass. Although these observations may lead athletes to believe that supraphysiological levels of GH will improve sporting performance, the contrary is suggested by acromegaly (a condition associated with GH hypersecretion) which is associated by muscle weakness, diabetes, and cardiomyopathy; however, acromegaly frequently remains undiagnosed for many years following its onset. During the early prediagnosis years, anecdotal evidence suggests that patients may experience increased strength and physical performance. ${ }^{40}$

\section{Bone and connective tissue}

GH plays an important role as an anabolic agent in connective tissue in human skeletal muscle and tendon, which provide a matrix to transmit force from individual muscle fibres to the bone. ${ }^{41,42}$ Therefore, a strengthened connective tissue would give a stronger and more strain-resistant muscle and tendon unit. It is for this reason that $\mathrm{GH}$ has been used by athletes to treat muscle and tendon injuries. Similarly GH administration improves bone strength both through a direct effect and indirectly through increased intestinal calcium absorption and serum vitamin D concentrations. ${ }^{43,44}$ It is important, however, to consider that in normal physiology, GH is secreted in pulses and this natural pulsatile and variable GH concentration cannot be replicated by a single GH dose, which will result in a single peak and will subsequently decline.

Previous work undertaken by Goldspink et $\mathrm{al}^{45}$ showed in rabbit experiments that the IGF-I mRNA increased in the stretched or stimulated muscles but not in resting control muscles. Following cloning and sequencing of this RNA, it was concluded that this was derived from the insulin-like growth factor gene by alternative splicing. This is particularly relevant for understanding the etiology and the development of possible treatment in muscle wasting conditions such as sarcopenia. ${ }^{46}$

\section{GH administration studies - what have we learnt? $\mathrm{GH}$ administration in $\mathrm{GH}$ deficient patients}

GH administration in both adults and children with GH deficiency increases muscle mass ${ }^{47-49}$ but findings have been mixed regarding the effect of GH on muscle strength. A large number of $\mathrm{GH}$ administration studies have failed to show any significant improvements on muscle strength. ${ }^{8,50-54}$ In these studies, GH was administered using a wide range of doses $(10 \mu \mathrm{g} / \mathrm{kg} /$ day $-40 \mu \mathrm{g} / \mathrm{kg} /$ day $)$ and duration ( 4 hours -12 weeks). Consequently there is a significant debate about the relationship between muscle mass increase and increased muscle strength. It is possible that a longer treatment period of more than 6 months may be necessary to show performance benefits, similar to those used in trials of people with GH deficiency. GH administration significantly improves functional capacity and quality of life. The results of these studies have been discussed in recent reviews. ${ }^{55,56}$

\section{$\mathrm{GH}$ administration in young athletes}

Two recent studies have demonstrated a positive performance effect following $\mathrm{GH}$ administration to young male amateur athletes. ${ }^{8,28}$

In a study from Australia, the impact of GH administration was assessed on three performance metrics. These included a measure of anaerobic performance using the Wingate test, maximal strength using the isometric dead-lift test, and maximal explosive power using a single vertical jump height. The treatment period lasted 6 weeks and although no evidence was found to suggest an improved anaerobic capacity in women, a significant improvement was reported in men receiving $\mathrm{GH}$ either alone or in combination with testosterone. No significant effect was observed in levels of maximal strength or maximal explosive power in either gender or any treatment group.

A further study involving past abusers of anabolic steroids showed improved strength following GH administration. ${ }^{28}$ The results of both studies should be treated with some caution as not all measures of performance were altered. Further studies are needed, particularly in women.

\section{$\mathrm{GH}$ administration in the elderly population}

The first study to demonstrate a performance effect in older men was a 6-month randomized GH administration trial. ${ }^{57}$ The study found that while coadministration of GH with testosterone produced the most significant changes on the investigated variables, the administration of GH or testosterone alone produced significant results when compared to the placebo treatment. The second study involved a shorter $\mathrm{GH}$ administration period of 16 weeks and also examined the effects of its administration on performance. ${ }^{58}$ This study concluded that $\mathrm{GH}$ administration resulted in significant gains in total and appendicular lean mass, muscle strength, and aerobic endurance which were accompanied by significant reductions in whole-body and trunk fat. The effects were enhanced with concomitant testosterone administration. 
In addition, a further study has suggested that there is significant evidence to suggest that resistance training in combination with $\mathrm{GH}$ administration will lead to a significant increase in IGF-I gene expression and muscle strength.

Despite these findings, it may not be possible to extrapolate them to younger adults because of the marked differences in $\mathrm{GH}$ secretion between young and old.

\section{Health risks related to $\mathbf{G H}$ abuse}

The potential risks of GH use by athletes are not well appreciated because relevant epidemiological data are lacking. Both hGH and IGF-I are potent mitogenic and anti-apoptotic agents, and several reports have shown an association between IGF-I concentration and the incidence of breast, prostate, and colorectal cancers ${ }^{59-61}$ but evidence that $\mathrm{GH}$ is carcinogenic is lacking.

In a critical evaluation of the safety of recombinant human GH, the GH and IGF Research Society concluded in a consensus statement that for the current approved indications, $\mathrm{GH}$ administration is safe. The society also concluded that there is currently insufficient evidence regarding the longer term safety of $\mathrm{GH}$ and it recommended that epidemiological studies were set up to monitor this closely. ${ }^{62}$

Acromegaly can cause insulin resistance, glucose intolerance, peripheral edema, and arthralgias and these may be experienced by athletes abusing GH in large quantities. Furthermore, GH abuse and concomitant use of anabolic steroids were identified as possible etiological factors in the development of bilateral internal laryngocoeles in an elite bodybuilder. ${ }^{63}$

A comprehensive review of adverse effects reported with supraphysiological GH levels is available in Buzzini 2007 and a summary of this has been provided in Table $1 .{ }^{64}$ In addition to the health risks directly associated with the use of excess $\mathrm{GH}$, there are additional risks associated with contamination if the GH is often sourced illegally. Although the availability of recombinant human growth hormone is expected to dominate the black market, some GH is extracted from cadavers and may be contaminated with the prion that causes Creutzfeldt-Jakob disease.

\section{Challenges in developing a robust GH detection methodology}

A further attraction to the use of $\mathrm{GH}$ by athletes is the lack of a reliable method to detect GH use more than 12 hours following its administration. Even though many efforts have been made to develop analytical methodology for distinguishing between endogenous $\mathrm{GH}$ and exogenous rhGH, it has proven
Table I Summary of adverse effects found to be associated with excess levels of growth hormone in patients suffering with acromegaly

\begin{tabular}{ll}
\hline Area of concern & Main symptoms \\
\hline $\begin{array}{l}\text { Cardiovascular } \\
\text { Pulmonary }\end{array}$ & $\begin{array}{l}\text { Reduced cardiac function } \\
\text { Sleep apnea and respiratory failure } \\
\text { Musculoskeletal }\end{array}$ \\
$\begin{array}{l}\text { Gigantism and increasing muscle weakness } \\
\text { Increasing insulin resistance and the onset } \\
\text { of diabetes mellitus }\end{array}$ \\
Neurological & $\begin{array}{l}\text { Frequent headaches and instances of idiopathic } \\
\text { intracranial hypertension }\end{array}$ \\
Malignancy & $\begin{array}{l}\text { Possible increased risk of leukemia and solid } \\
\text { tumors such as breast, colon, prostate, and } \\
\text { endometrial cancer } \\
\text { Coarsened facial appearance, abnormal } \\
\text { enlargement of the extremities of the skeleton }\end{array}$ \\
Visceromegaly & $\begin{array}{l}\text { Exhibited in organs such as tongue, thyroid gland, } \\
\text { salivary glands, liver, spleen, kidney, and prostate }\end{array}$ \\
\hline
\end{tabular}

difficult to develop a reliable method. Detecting GH abuse by measurement of GH directly is not practical because of its pulsatile release and sensitivity to a number of external influences, including exercise and stress.

A single baseline or random measurement of circulating $\mathrm{GH}$ concentration has little diagnostic significance, either clinically or in the context of GH doping. ${ }^{65}$ This was demonstrated using blood samples collected from 500 elite athletes in the period leading up to the Sydney Olympics, as part of the campaign Io non rischio la salute (I'm not risking my health) conducted by the Italian Olympic Committee (CONI) in 1999. There were a large number of blood samples, including one from a gold medalist, who had markedly high $\mathrm{GH}$ values. Following assessment of these findings using the serum concentrations of biochemical markers of the GH function, it was concluded that there was no evidence to suggest GH abuse. ${ }^{66}$

Developing a detection method for $\mathrm{GH}$ abuse using urinary GH measurements has also proven challenging because GH urinary excretion does not accurately reflect the blood concentration and can rise following exercise alongside the increased excretion of albumin and other proteins. Consequently, high urinary GH concentrations would not necessarily be indicative of GH doping. Nevertheless a significant amount of research has been invested in this area. This is because blood testing is relatively new in sports as this type of testing poses both potential logistical and legal issues. ${ }^{67}$ To date, no official court has formally determined whether mandatory blood testing in sport for performance enhancing substances violates any internationally or nationally recognized individual rights to privacy 
or bodily integrity. In terms of logistical challenges, blood collection is more difficult than urine specimen collection as blood samples call for additional handling to ensure they arrive at the anti-doping laboratory in a condition that allows for analysis to minimize risk. However, the use of blood over urine in anti-doping testing has the advantage that specimen manipulation is nearly impossible. ${ }^{68}$

Nevertheless, the development of a reliable urine detection test has proved an impossible task to date. Leger in 1995 concluded that $\mathrm{GH}$ excretion varies too widely, as assessed in normally growing and growth hormone-deficient children, to be used as a clinical GH quantification method. ${ }^{69}$ Attempts to develop a GH detection test using GH measurements in urine by Saugy et $\mathrm{al}^{70}$ have been unsuccessful. As well as the variability, the much lower GH concentration in urine compared with blood make measurement difficult. Circulating $\mathrm{GH}$ is cleared from the bloodstream through degradation, predominantly in the liver and kidney. In the kidney, GH is cleared principally by glomerular filtration, uptake and degradation in the proximal tubule, and minute quantities of intact GH, only $0.001 \%-0.010 \%$ of pituitary GH secretion, appear in the urine.

Two different but complementary approaches have been developed to detect $\mathrm{GH}$ abuse; both methodologies have merits and drawbacks depending on the testing scenario. The first is based on the detection of different pituitary GH isoforms and can detect athletes who have administered rhGH within 12-24 hours of the test; this methodology is therefore most suitable for unannounced out of competition testing. The second method relies on measurement of GH-dependent markers and has a longer window of opportunity of up to 2 weeks since last $\mathrm{GH}$ administration. This methodology would be suitable for both out and in competition testing scenarios.

\section{The GH isoform method}

This method is currently the only method approved by WADA and the IOC and was first implemented at the Athens Olympic Games in 2004. ${ }^{71}$ This method involves the analysis of $\mathrm{GH}$ isoforms and was originally referred to as the "differential isoform assay method".

The pituitary gland secretes a number of GH isoforms; the most abundant is the $22 \mathrm{kDa}$ isoform but there are other minor products of gene transcription and post-transcription modification. The most prominent of these is a $20 \mathrm{kDa}$ isoform that normally circulates at concentrations averaging around $10 \%$ of the $22 \mathrm{kDa}$ isoform. By contrast, exogenous rhGH contains only the $22 \mathrm{kDa}$ isoform. When exogenous
rhGH is administered, there is a marked decrease in the endogenous pituitary GH production because of negative feedback and a fall in non- $22 \mathrm{kDa}$ isoforms. ${ }^{72}$

The presence of different isoforms provides the basis for the detection method developed by $\mathrm{Wu}$, Bidlingmaier, and Strasburger. This methodology distinguishes between circulating endogenous GH secretion and exogenous recombinant human $\mathrm{GH}$ (but not pituitary-derived $\mathrm{GH}$ ) administration by measuring the ratio between the concentration of different isoforms.

The isoform test has been validated in a range of settings and findings have shown that the ratio of $22 \mathrm{k}$ to total GH is stable across several populations regardless of their age, gender, body weight, or height. ${ }^{73}$ It is not yet confirmed whether the ratio is stable across all ethnic groups although preliminary findings suggest little impact from ethnicity. ${ }^{74}$ Acute bouts of exercise reduce the sensitivity of this test slightly but have no adverse impact on false positive rates. ${ }^{75,76}$

The major disadvantage of this method is that $\mathrm{GH}$ isoforms have short half-lives and spontaneous $\mathrm{GH}$ secretion returns to baseline 12-24 hours after the last dose of GH. This means that the window of opportunity for detection is short, between 12 and 24 hours.

The isoform method cannot detect pituitary-derived cadaveric GH doping (pituitary-derived GH from both animals and humans is still commercially available) or the abuse of GH secretagogues or IGF-I because the GH isoform ratio is unchanged in each of these situations. Other detection methodologies such as the GH biomarker approach would be required to identify doping in this scenario.

\section{Catching the first $\mathrm{GH}$ cheat using the isoform test}

Following its implementation in 2004, the first adverse analytical findings of the isoform test was in November 2009 when Terry Newton, a British rugby league player, tested positive. ${ }^{77}$ Newton subsequently admitted to injecting $\mathrm{GH}$ in an attempt to recover from injuries and alleged that he knew a number of other rugby league players who were also using GH. Subsequently there have been further adverse analytical findings.

The low detection rate is likely to reflect its limited window of opportunity as most of the tests have been immediately postcompetition.

\section{The $\mathrm{GH}$ biomarker approach}

The second GH detection methodology currently being considered for implementation by WADA is the "GH marker" approach or "GH biomarker" approach. This method involves 
the measurement of circulating concentrations of two GHsensitive proteins, IGF-I, and Procollagen III N-Terminal Propeptide (PIIINP), which are known to increase in a dosedependent manner following $\mathrm{GH}$ administration. ${ }^{78-80}$

The GH marker test utilizes gender specific mathematical functions which include the logged values of serum IGF-I and PIIINP to produce a detection GH-2000 score, named after the project that first established the method. ${ }^{81,82}$ A positive test would be declared if the values exceeded those found in a normal healthy population of elite athletes. ${ }^{83-85}$ The score was originally calibrated against a large sample of 813 elite athletes which was also used to assess any bias caused by the age of the individual or other characteristics of the athletes. ${ }^{83}$

The resulting age adjusted function for men is:

$$
\begin{aligned}
\mathrm{GH}-2000 \text { score }= & -6.586+2.905 * \log (\mathrm{PIIINP}) \\
& +2.100 * \log (\mathrm{IGF}-1)-101.737 / \text { age }
\end{aligned}
$$

where age is measured in years.

Similar calibration was undertaken for female elite athletes, leading to the age-adjusted derived score for women:

$$
\begin{aligned}
\mathrm{GH}-2000 \text { score }= & -8.459+2.454 * \log (\mathrm{PIIINP}) \\
& +2.195 * \log (\mathrm{IGF}-\mathrm{I})-73.666 / \text { age }
\end{aligned}
$$

Both formulae were standardized to give a mean 0 and standard deviation 1 over the population of elite athletes.

The marker approach has a major advantage over the isoform test in that the biomarkers are more stable in serum than GH but rise dramatically after $\mathrm{GH}$ administration and only slowly return to baseline therefore providing a longer "window of opportunity" to detect an athlete who has been abusing GH.

The test has been under development since 1996 and a large number of studies have been undertaken to ensure the GH marker methodology is robust and reliable and would withstand the scrutiny anticipated in a Court of Arbitration in Sport. The following areas have been assessed:

\section{Responsiveness and disappearance kinetics following $\mathrm{GH}$ administration}

The markers chosen for the GH test are required to respond to $\mathrm{GH}$ administration in both men and women and across a wide range of ethnic groups.

Double-blind placebo-controlled GH administration randomized controlled trials have been undertaken to assess the responsiveness of a range of markers to $\mathrm{GH}$ administration in male and female amateur athletes. ${ }^{78,86,87}$ Results showed that the combination of IGF-I and PIIINP provides very good discrimination between $\mathrm{GH}$ administered individuals and those who received placebo, without placing any particular group at an increased risk of a false positive. ${ }^{78,81,88} \mathrm{~A}$ further doubleblind $\mathrm{GH}$ administration study suggests that the response to $\mathrm{GH}$ in other ethnic groups does not differ significantly from white European amateur athletes.

The responsiveness varied between men and women but this was expected as it is known that there is sexual dimorphism in the GH-IGF axis. Women are more resistant to the actions of $\mathrm{GH}$ and therefore the increase in markers was smaller than that observed in men. ${ }^{78,86}$ Nevertheless the responsiveness was sufficient to discriminate reliably between each of the treatment groups with reasonable sensitivity.

The disappearance kinetics for both IGF-I and PIIINP indicate that detection is possible for as long as 2 weeks after cessation of GH abuse. ${ }^{88}$ In particular, PIIINP has a much longer half-life than GH and IGF-I thereby lengthening the 'window of opportunity' for detection. ${ }^{89}$

\section{The impact of acute endurance-type exercise}

As testing often occurs in the immediate postcompetition setting, it is important that exercise does not change IGF-I and PIIINP sufficiently to affect the performance of the test. During a GH administration study, IGF-I and PIIINP increased by $20 \%$ and $10.2 \%$, respectively, following an acute bout of exercise but this increase was small in comparison with the much larger $300 \%$ increase in the markers that occurred following $\mathrm{GH}$ administration. ${ }^{78,88}$

\section{The impact of intra-individual variability}

The intra-individual variation (day-to-day stability) of the measured concentration of these markers should be small in placebo-treated individuals, thus allowing the determination of reliable physiological ranges.

Results from four longitudinal studies following athletes for a period of up to 12 months showed remarkably consistent results, with no apparent difference between amateur and elite athletes. The intra-individual variability for IGF-I varied between $13.9 \%$ and $16 \%$ while the variability for PIIINP varies from $12 \%$ to $19 \%$ which is no greater than the measurement error involved with immunoassay laboratory analysis. ${ }^{90}$

\section{Impact of injury}

Injuries are common in sport and these may cause an increase in PIIINP ${ }^{91,92}$ and IGF-I. ${ }^{93}$ In particular, skeletal injury alters PIIINP as this is a marker of soft tissue and bone turnover. ${ }^{93,94}$ Following a tibial shaft fracture, bone turnover increases for at least 24 weeks and was accompanied by an increase in PIIINP. ${ }^{91}$ Therefore, it was vital to ensure that no athlete 
would be falsely accused of GH doping under the proposed methodology because of an injury.

A specifically designed study followed 143 men and 40 women after a sporting injury. There was no change in IGF-I over the 12-week follow-up, but PIIINP increased by approximately $20 \%$, reaching a peak $2-3$ weeks after injury. The magnitude and duration of this increase was dependent on the severity and nature of the injury but under no situation did the rise cause any false-positive readings in the proposed test. ${ }^{95}$ Previous studies have shown with more serious illness or injury that IGF-I concentrations fall and so while the above study did not study the full range of athletic injury, it is also unlikely that more serious injuries would cause a false positive because any further increase in PIIINP would be offset by a reduction in IGF-I.

\section{Impact of ethnicity}

Published studies of 'non-elite athlete' healthy volunteers have found little difference in IGF-I concentrations between ethnic groups ${ }^{96-98}$ but it was important to confirm this in elite athletes. Two independent research groups undertook studies to examine whether there was any evidence to suggest a difference in circulating IGF-I and PIIINP between ethnic groups. One of these studies was a cross-sectional study of elite athletes that showed that although there are small differences in the mean values between ethnic groups - for example, the IGF-I concentrations in Afro-Caribbean men are approximately $8.2 \%$ lower than white European men - nearly all values lie within the $99 \%$ prediction intervals for white European athletes, regardless of ethnic background.

\section{Validation of methodology using independently collected data}

A confirmatory study was undertaken as a way of assessing the performance of the GH marker approach using another independent population. When the male GH-2000 formula was applied to an independent dataset obtained from the Institut für Dopinganalytik und Sportbiochemie Kreischa, $90 \%$ of the individuals who had received $\mathrm{GH}$ were correctly identified and there were no false-positives; these findings were similar to the results found in the GH-2000 dataset from which the formula was developed. ${ }^{79}$

\section{Impact of concomitant use of $\mathrm{GH}$ with other doping agents}

It is believed that athletes abusing GH do so in combination with other performance enhancing substances, such as anabolic steroids. It is therefore important that any proposed methodology will still be applicable in such a scenario. It is nearly impossible to replicate such circumstances in a research study, as the frequency, dosage, and combination of substances are not known but we can infer the outcome of such a scenario by examining the concomitant use of GH with other commonly used doping substances. A study performed in Australia showed that the post-GH rise in IGF-I was not suppressed by concomitant testosterone administration while the increase in PIIINP was larger. ${ }^{80}$

\section{The need for assay standardization}

The GH marker approach, just like the isoform test, currently relies on the use of immunoassays to quantify IGF-I and PIIINP. Following the completion of the original GH-2000 project, the IOC was advised in 1999 to establish assays within their own laboratory system ${ }^{99}$ but they failed to heed this recommendation. Unlike the isoform test, the GH-2000 and GH-2004 research groups that developed the GH marker methodology have relied on commercial immunoassays resulting in limited control of any changes made to the reagents and the standards used in the assay. This coupled with the fact that there is currently no reliable international standard for PIIINP has meant that the numerical values obtained from different assays vary and are prone to change.

Assay manufacturers update their immunoassays over time and there is no standardization process for the development of immunoassays by different manufacturers. These are key areas that need to be clarified before introduction of the "marker" test. It is the nature of immunoassays that measurements are not absolute and inevitably are a function of the reagents and conditions used in the assay.

This has been a major stumbling block delaying the implementation of this methodology by WADA. WADA have now funded a significant research project aiming to address the impact of using commercial immunoassays by deriving assay specific cut-offs with modern assays for the GH markers. Following implementation of the tests, these cut-offs will be reviewed frequently to ensure such threshold levels remain relevant to the assays used at the time of testing.

\section{Other GH detection methods - past and future}

Over the years a number of other groups assessed whether other GH dependent biomarkers can detect GH abuse. The Institut für Dopinganalytik und Sportbiochemie in Kreischa, Germany, proposed a detection methodology through the 
use of a discriminant function based on the concentrations of IGF-I, PIIINP, and IGFBP-3. ${ }^{100}$ The Australian Japanese Consortium, which studied the effects of GH and testosterone, proposed using an alternative bone marker (carboxy terminal cross-linked telopeptide of type I collagen) to PIIINP because this had a better discrimination during the wash-out phase because of the longer half-life of the Type 1 collagen marker. ${ }^{74}$ This approach has not been followed due to the lack of a second immunoassay which would be needed to comply with WADA laboratory guidance.

In the near future, mass spectrometry methods for IGF-I measurement will become available. Although immunoassays may continue to be used for screening because of the ease of use, it is likely that mass spectrometry methods will become the gold standard. It is unlikely, however, that such methods for the detection of PIIINP will be available for some time.

\section{Serum proteomic profiling}

Serum proteomic profiling using surface-enhanced laser desorption/ionization time-of-flight mass spectrometry can detect alterations in multiple proteins after $\mathrm{GH}$ administration. By studying protein profiles in blood samples from individuals who had received $\mathrm{GH}$ and controls, Chung et al identified the hemoglobin alpha-chain as a novel serum biomarker as it changed after hGH administration and provided good discrimination between the two groups. ${ }^{101}$ This study has not been repeated and at present the sensitivity or specificity of this approach has not been assessed.

\section{Surface plasmon resonance}

Surface plasmon technology is a non-labeled optical methodology that measures the refractive index of small quantities of a material adsorbed onto a metal surface allowing measurement of mass. ${ }^{87}$ The intention is that if successful this technology could be used to quantify the concentration of $\mathrm{GH}$ dependent markers, instead of using conventional immunoassays. However, early findings suggest that the use of this technology does not yield the same level of sensitivity as currently available commercial immunoassays.

\section{The use of pharmaceutical markers in $\mathrm{GH}$ preparations}

A recent publication ${ }^{102}$ reviewed pharmaceutical proposals for enabling easier detection of $\mathrm{GH}$ abuse by modifying current GH pharmaceutical preparations. Three theoretical proposals have been put forward for this: a. The development of a new epitope by altering the amino acid sequence of the protein whilst maintaining its biological activity. This could then be used in an immunoassay to quantify this protein.

b. Covalently attaching a marker to the protein that would be measurable.

c. The addition of a traceable marker to synthetic GH formulation that could be easily detected by a biological or chemical assay.

This approach suffers from the distinct risk that athletes will more than likely avoid the use of this formulation, opting for unregulated unmodified GH which would potentially pose even a greater health risk. There are also ethical concerns about exposing patients to a marker that has no medical benefit to them. Investment in this research area would require substantial efforts, and it would be more practical to concentrate efforts on refining detection methodologies currently under development.

\section{The future of GH doping - gene doping}

Athletes are continuing to seek new ways of improving their physical performance and patterns of performance enhancing drug abuse have changed as developments in anti-doping technology are made. Athletes have always been ahead of the "doping game" with athletes abusing GH 10 years before it was accepted as an effective medical treatment in adults. ${ }^{31}$ It is thought that the next era of doping will be that of gene doping, where currently there are no methodologies for detecting such tools.

There are concerns that gene doping could be used (or might already be in use) in a variety of athletic settings ${ }^{103}$ utilizing the advances in the treatment of serious diseases such as hemophilia ${ }^{104}$ and X-linked severe combined immunodeficiency disease. WADA has defined gene or cell doping as the "nontherapeutic use of genes, genetic elements, and/or cells that have the capacity to enhance athletic performance". ${ }^{105}$

In sport, gene therapy might be used to heal tissue defects more efficiently following trauma thereby minimizing the effect of sport injuries. Furthermore, gene therapy has the potential to modify normal metabolism. Erythropoietin, hGH, insulin-like growth factor-1 (IGF-I), peroxisome proliferator activated receptor-delta, and myostatin inhibitor genes have all been identified as potential targets for gene doping. ${ }^{106-108}$

The use of gene therapy carries a number of potential risks partly as a result of the toxicity of the gene transfer vectors and partly because of uncontrolled transcription of the gene 
itself. For example, overexpression of the erythropoietin gene may lead to increased blood viscosity of the blood and the risk of clotting. ${ }^{103}$ The effects of gene therapy to increase IGF-I or GH production are unknown but may lead to problems seen in individuals with acromegaly or the development of cancer.

Detection of gene therapy abuse is difficult, mainly because any effects of the transferred gene are similar to endogenous function. It may be possible to detect the viral vector or the gene protein product if this is present in the circulation in supraphysiological quantities.

\section{Conclusions}

Despite a widespread belief that $\mathrm{GH}$ abuse will enhance sporting performance, there is limited evidence to support this. In addition, its abuse is associated with significant health risks and athletes should take this into consideration when contemplating its use for enhancing their performance. Despite a number of significant challenges, both physiological and logistical, there now are a number of promising $\mathrm{GH}$ detection methodologies under way. These will help to protect the health and safety of athletes, the integrity of sport, and the principles of fair play.

\section{Acknowledgments}

The GH project is funded by the United States Anti-Doping Agency and the World Anti-Doping Agency. Our thanks go to the rest of the GH-2004 team: Eryl Bassett, Nishan Guha, David Cowan, and Christiaan Bartlett and the GH-2000 project for their legacy of samples and information.

\section{Disclosure}

No conflicts of interest were declared in relation to this paper.

\section{References}

1. Brown-Sequard CE. The effects produced in man by subcutaneous injections of a liquid obtained from the testicles of animals. Lancet. 1889;2:105-107.

2. Li CH, Apkoff H. Preparation and properties of growth hormone from human and monkey pituitary glands. Science. 1956;124:1293-1294.

3. Raben MS. Treatment of a pituitary dwarf with human growth hormone. J Clin Endocrinol Metab. 1958;18:901-903.

4. Raben MS. Growth hormone. 2. Clinical use of human growth hormone N Engl J Med. 1962;266:82-86.

5. Hintz RL. Growth hormone: uses and abuses. BMJ. 2004;328: 907-908.

6. Duchaine D. Underground steroid handbook. Santa Monica, CA: OEM. 1982.

7. Haycock B. Growing beyond what nature intended - growth factors take us to the next level of sophistication in bodybuilding (Part III: GH, IGF-1, insulin, and thryoid to enhance anabolic effects of androgens) [serial online]. Available from: http://www.mesomorphosis.com/articles/ haycock/growth-factors-03.htm. Accessed June 03, 2011.
8. Meinhardt U, Nelson AE, Hansen JL, et al. The effects of growth hormone on body composition and physical performance in recreational athletes: a randomized trial. Ann Intern Med. 2010;152:568-577.

9. Dubin CJ. Commision of inquiry into the use of drugs and banned practices intended to increase athletic performance. Ottawa, ON: Canadian Publishing Center; 1990.

10. Kicman AT, Cowan DA. Peptide hormones and sport: misuse and detection. Br Med Bull. 1992;48:496-517.

11. Hoberman JM. Mortal engines: the science of performance and the dehumanization of sport. New York: Free Press; 1992.

12. Zorpette G. All doped up - and going for the gold. Sci Am. 2000;282: 20-22.

13. Williams L, Fainaru-Wada M. Game of shadows: Barry Bonds, Balco, and the steroids scandal that rocked professional sports. New York: Gotham Books; 2006.

14. Pinsent $\mathrm{M}$. HGH - the perspective of an elite rower and journalist. Growth Horm IGF Res. 2009;19:288.

15. Reuters. Pfizer to pay $\$ 35 \mathrm{mln}$ in Genotropin settlements. 2007. Available from: http://www.reuters.com/article/2007/04/03/idUSWNAS544720070403. Accessed June 03, 2011.

16. Faria AC, Bekenstein LW, Booth RA Jr, et al. Pulsatile growth hormone release in normal women during the menstrual cycle. Clin Endocrinol (Oxf). 1992;36:591-596.

17. Bermann M, Jaffe CA, Tsai W, DeMott-Friberg R, Barkan AL. Negative feedback regulation of pulsatile growth hormone secretion by insulinlike growth factor I. Involvement of hypothalamic somatostatin. J Clin Invest. 1994;94:138-145.

18. Hartman ML, Veldhuis JD, Johnson ML, et al. Augmented growth hormone $(\mathrm{GH})$ secretory burst frequency and amplitude mediate enhanced GH secretion during a two-day fast in normal men. J Clin Endocrinol Metab. 1992;74:757-765.

19. Iranmanesh A, Lizarralde G, Veldhuis JD. Age and relative adiposity are specific negative determinants of the frequency and amplitude of growth hormone $(\mathrm{GH})$ secretory bursts and the half-life of endogenous GH in healthy men. J Clin Endocrinol Metab. 1991;73:1081-1088.

20. Kanaley JA, Weltman JY, Veldhuis JD, Rogol AD, Hartman ML, Weltman A. Human growth hormone response to repeated bouts of aerobic exercise. J Appl Physiol. 1997;83:1756-1761.

21. Janssen JA, Stolk RP, Pols HA, Grobbee DE, de Jong FH, Lamberts SW. Serum free IGF-I, total IGF-I, IGFBP-1 and IGFBP-3 levels in an elderly population: relation to age and sex steroid levels. Clin Endocrinol (Oxf). 1998;48:471-478.

22. Donahue LR, Hunter SJ, Sherblom AP, Rosen C. Age-related changes in serum insulin-like growth factor-binding proteins in women. J Clin Endocrinol Metab. 1990;71:575-579.

23. Wheldon A, Savine RL, Sonksen PH, Holt RI. Exercising in the cold inhibits growth hormone secretion by reducing the rise in core body temperature. Growth Horm IGF Res. 2006;16:125-131.

24. Holt RI, Webb E, Pentecost C, Sonksen PH. Aging and physical fitness are more important than obesity in determining exercise-induced generation of GH. J Clin Endocrinol Metab. 2001;86:5715-5720.

25. Weltman A, Weltman JY, Hartman ML, et al. Relationship between age, percentage body fat, fitness, and 24-hour growth hormone release in healthy young adults: effects of gender. $J$ Clin Endocrinol Metab. 1994; 78:543-548.

26. Rigamonti AE, Cella SG, Marazzi N, Di LL, Sartorio A, Muller EE. Growth hormone abuse: methods of detection. Trends Endocrinol Metab. 2005;16:160-166.

27. VanHelder WP, Goode RC, Radomski MW. Effect of anaerobic and aerobic exercise of equal duration and work expenditure on plasma growth hormone levels. Eur J Appl Physiol Occup Physiol. 1984;52:255-257.

28. Graham MR, Baker JS, Evans P, et al. Physical effects of short-term recombinant human growth hormone administration in abstinent steroid dependency. Horm Res. 2008;69:343-354.

29. Franke WW, Berendonk B. Hormonal doping and androgenization of athletes: a secret program of the German Democratic Republic government. Clin Chem. 1997;43:1262-1279. 
30. Kraemer W, Nindl BC, Rubin MR. Growth hormone: physiological effects of exogenous administration. In: Bahrke MS, Yesalis CE, editors. Performance enhancing substances in sport and exercise. Champaign, IL: Human Kinetics. 2002:65-78.

31. Sonksen PH. Insulin, growth hormone and sport. J Endocrinol 2001;170:13-25.

32. Binnerts A, Swart GR, Wilson JH, et al. The effect of growth hormone administration in growth hormone deficient adults on bone, protein, carbohydrate and lipid homeostasis, as well as on body composition. Clin Endocrinol (Oxf). 1992;37:79-87.

33. Mekala KC, Tritos NA. Effects of recombinant human growth hormone therapy in obesity in adults: a meta analysis. J Clin Endocrinol Metab. 2009;94:130-137.

34. Crist DM, Peake GT, Egan PA, Waters DL. Body composition response to exogenous GH during training in highly conditioned adults. $J \mathrm{Appl}$ Physiol. 1988;65:579-584.

35. Fryburg DA, Gelfand RA, Barrett EJ. Growth hormone acutely stimulates forearm muscle protein synthesis in normal humans. Am J Physiol. 1991;260:E499-E504

36. Fryburg DA, Barrett EJ. Growth hormone acutely stimulates skeletal muscle but not whole-body protein synthesis in humans. Metabolism. 1993;42:1223-1227.

37. Lange KH, Isaksson F, Rasmussen MH, Juul A, Bulow J, Kjaer M. GH administration and discontinuation in healthy elderly men: effects on body composition, GH-related serum markers, resting heart rate and resting oxygen uptake. Clin Endocrinol (Oxf). 2001;55:77-86.

38. Welle S, Thornton C, Statt M, McHenry B. Growth hormone increases muscle mass and strength but does not rejuvenate myofibrillar protein synthesis in healthy subjects over 60 years old. JClin Endocrinol Metab. 1996;81:3239-3243.

39. Welle S. Growth hormone and insulin-like growth factor-I as anabolic agents. Curr Opin Clin Nutr Metab Care. 1998;1:257-262.

40. Sharp RJ. Land of the giants. Growth Horm IGF Res. 2009;19: 291-293.

41. Rennie MJ. Claims for the anabolic effects of growth hormone: a case of the emperor's new clothes? Br J Sports Med. 2003;37:100-105.

42. Doessing S, Kjaer M. Growth hormone and connective tissue in exercise. Scand J Med Sci Sports. 2005;15:202-210.

43. Lund B, Eskildsen PC, Lund B, Norman AW, Sorensen OH. Calcium and vitamin D metabolism in acromegaly. Acta Endocrinol (Copenh). 1981;96:444-450.

44. Burstein S, Chen IW, Tsang RC. Effects of growth hormone replacement therapy on 1,25-dihydroxyvitamin D and calcium metabolism. $J$ Clin Endocrinol Metab. 1983;56:1246-1251.

45. Goldspink G, Scutt A, Loughna PT, Wells DJ, Jaenicke T, Gerlach GF. Gene expression in skeletal muscle in response to stretch and force generation. Am J Physiol. 1992;262:R356-R363.

46. Goldspink G, Wessner B, Tschan H, Bachl N. Growth factors, muscle function, and doping. Endocrinol Metab Clin North Am. 2010; 39:169181, xi.

47. Cuneo RC, Salomon F, Wiles CM, Hesp R, Sonksen PH. Growth hormone treatment in growth hormone-deficient adults. I. Effects on muscle mass and strength. J Appl Physiol. 1991;70:688-694.

48. Jorgensen JO, Pedersen SA, Thuesen L, et al. Beneficial effects of growth hormone treatment in GH-deficient adults. Lancet. 1989; 1:1221-1225.

49. Tanner JM, Hughes PC, Whitehouse RH. Comparative rapidity of response of height, limb muscle and limb fat to treatment with human growth hormone in patients with and without growth hormone deficiency. Acta Endocrinol (Copenh). 1977;84:681-696.

50. Yarasheski KE, Campbell JA, Smith K, Rennie MJ, Holloszy JO, Bier DM. Effect of growth hormone and resistance exercise on muscle growth in young men. Am J Physiol. 1992;262:E261-E267.

51. Deyssig R, Frisch H, Blum WF, Waldhor T. Effect of growth hormone treatment on hormonal parameters, body composition and strength in athletes. Acta Endocrinol (Copenh). 1993;128:313-318.
52. Lange KH, Larsson B, Flyvbjerg A, et al. Acute growth hormone administration causes exaggerated increases in plasma lactate and glycerol during moderate to high intensity bicycling in trained young men. J Clin Endocrinol Metab. 2002;87:4966-4975.

53. Irving BA, Patrie JT, Anderson SM, et al. The effects of time following acute growth hormone administration on metabolic and power output measures during acute exercise. J Clin Endocrinol Metab. 2004;89:4298-4305.

54. Berggren A, Ehrnborg C, Rosen T, Ellegard L, Bengtsson BA, Caidahl K. Short-term administration of supraphysiological recombinant human growth hormone $(\mathrm{GH})$ does not increase maximum endurance exercise capacity in healthy, active young men and women with normal GH-insulin-like growth factor I axes. J Clin Endocrinol Metab. 2005;90:3268-3273.

55. Gibney J, Healy ML, Sonksen PH. The growth hormone/insulin-like growth factor-I axis in exercise and sport. Endocr Rev. 2007;28: 603-624.

56. Woodhouse LJ, Mukherjee A, Shalet SM, Ezzat S. The influence of growth hormone status on physical impairments, functional limitations, and health-related quality of life in adults. Endocr Rev. 2006;27:287-317.

57. Giannoulis MG, Sonksen PH, Umpleby M, et al. The effects of growth hormone and/or testosterone in healthy elderly men: a randomized controlled trial. J Clin Endocrinol Metab. 2006;91: 477-484.

58. Sattler FR, Castaneda-Sceppa C, Binder EF, et al. Testosterone and growth hormone improve body composition and muscle performance in older men. J Clin Endocrinol Metab. 2009;94:1991-2001.

59. Allen NE, Roddam AW, Allen DS, et al. A prospective study of serum insulin-like growth factor-I (IGF-I), IGF-II, IGF-binding protein-3 and breast cancer risk. Br J Cancer. 2005;92:1283-1287.

60. Nabarro JD. Acromegaly. Clin Endocrinol (Oxf). 1987;26:481-512.

61. Yarasheski KE. Growth hormone effects on metabolism, body composition, muscle mass, and strength. Exerc Sport Sci Rev. 1994; $22: 285-312$

62. Critical evaluation of the safety of recombinant human growth hormone administration: statement from the Growth Hormone Research Society. $J$ Clin Endocrinol Metab. 2001;86:1868-1870.

63. Moor JW, Khan MI. Growth hormone abuse and bodybuilding as aetiological factors in the development of bilateral internal laryngocoeles. A case report. Eur Arch Otorhinolaryngol. 2005;262:570-572.

64. Buzzini SR. Abuse of growth hormone among young athletes. Pediatr Clin North Am. 2007;54:823-843, xiii.

65. Healy ML, Russell-Jones D. Growth hormone and sport: abuse, potential benefits, and difficulties in detection. Br J Sports Med. 1997;31:267-268.

66. Armanini D, Faggian D, Scaroni C, Plebani M. Growth hormone and insulin-like growth factor I in a Sydney Olympic gold medallist. $\mathrm{Br} J$ Sports Med. 2002;36:148-149.

67. Mitten MJ. Legal issues arising out of blood testing for human growth hormone. Drug Test Anal. 2009;1:434-436.

68. Uryasz F. Issues of testing for hGH: collection. Drug Test Anal. 2009; $1: 437-438$.

69. Leger J, Reverchon C, Porquet D, Noel M, Czernichow P. The wide variation in urinary excretion of human growth hormone in normal growing and growth hormone-deficient children limits its clinical usefulness. Horm Res. 1995;44:57-63.

70. Saugy M, Cardis C, Schweizer C, Veuthey JL, Rivier L. Detection of human growth hormone doping in urine: out of competition tests are necessary. J Chromatogr B Biomed Appl. 1996;687:201-211.

71. Saugy M, Robinson N, Saudan C, Baume N, Avois L, Mangin P. Human growth hormone doping in sport. Br J Sports Med. 2006;40: i35-i39.

72. Hashimoto Y, Kamioka T, Hosaka M, et al. Exogenous 20K growth hormone $(\mathrm{GH})$ suppresses endogenous $22 \mathrm{~K}$ GH secretion in normal men. J Clin Endocrinol Metab. 2000;85:601-606. 
73. Tsushima T, Katoh Y, Miyachi Y, et al. Serum concentration of $20 \mathrm{~K}$ human growth hormone $(20 \mathrm{~K} \mathrm{hGH})$ measured by a specific enzymelinked immunosorbent assay. Study Group of $20 \mathrm{~K}$ hGH. J Clin Endocrinol Metab. 1999;84:317-322.

74. Nelson AE, Ho KK. A robust test for growth hormone doping - present status and future prospects. Asian J Androl. 2008;10:416-425.

75. Wallace JD, Cuneo RC, Bidlingmaier M, et al. Changes in non-22kilodalton $(\mathrm{kDa})$ isoforms of growth hormone $(\mathrm{GH})$ after administration of 22-kDa recombinant human GH in trained adult males. $J$ Clin Endocrinol Metab. 2001;86:1731-1737.

76. Wallace JD, Cuneo RC, Bidlingmaier M, et al. The response of molecular isoforms of growth hormone to acute exercise in trained adult males. J Clin Endocrinol Metab. 2001;86:200-206.

77. BBC Sports. Wakefield's Terry Newton suspended over dope test 2010. Available from: http://news.bbc.co.uk/sport2/hi/rugby_league/ super_league/wakefield/8520770.stm. Accessed June 07, 2011.

78. Longobardi S, Keay N, Ehrnborg C, et al. Growth hormone (GH) effects on bone and collagen turnover in healthy adults and its potential as a marker of GH abuse in sports: a double blind, placebo-controlled study. The GH-2000 Study Group. J Clin Endocrinol Metab. 2000;85:1505-1512.

79. Erotokritou-Mulligan I, Bassett EE, Kniess A, Sonksen PH, Holt RI. Validation of the growth hormone $(\mathrm{GH})$-dependent marker method of detecting $\mathrm{GH}$ abuse in sport through the use of independent data sets. Growth Horm IGF Res. 2007;17:416-423.

80. Nelson AE, Meinhardt U, Hansen JL, et al. Pharmacodynamics of growth hormone abuse biomarkers and the influence of gender and testosterone: a randomized double-blind placebo-controlled study in young recreational athletes. J Clin Endocrinol Metab. 2008;93:2213-2222.

81. Powrie JK, Bassett EE, Rosen T, et al. Detection of growth hormone abuse in sport. Growth Horm IGF Res. 2007;17:220-226.

82. Bassett EE, Erotokritou-Mulligan I. Statistical issues in implementing the marker method. Growth Horm IGF Res. 2009;19:361-365.

83. Healy ML, Dall R, Gibney J, et al. Toward the development of a test for growth hormone $(\mathrm{GH})$ abuse: a study of extreme physiological ranges of GH-dependent markers in 813 elite athletes in the postcompetition setting. J Clin Endocrinol Metab. 2005;90:641-649.

84. Erotokritou-Mulligan I, Bassett EE, Cowan DA, et al. Influence of ethnicity on IGF-I and procollagen III peptide (P-III-P) in elite athletes and its effect on the ability to detect GH abuse. Clin Endocrinol (Oxf). 2009;70:161-168.

85. Nelson AE, Howe CJ, Nguyen TV, et al. Influence of demographic factors and sport type on growth hormone-responsive markers in elite athletes. J Clin Endocrinol Metab. 2006;91:4424-4432.

86. Dall R, Longobardi S, Ehrnborg C, et al. The effect of four weeks of supraphysiological growth hormone administration on the insulin-like growth factor axis in women and men. GH-2000 Study Group. J Clin Endocrinol Metab. 2000;85:4193-4200.

87. Holt RI, Sonksen PH. Growth hormone, IGF-I and insulin and their abuse in sport. Br J Pharmacol. 2008;154:542-556.

88. Wallace JD, Cuneo RC, Baxter R, et al. Responses of the growth hormone $(\mathrm{GH})$ and insulin-like growth factor axis to exercise, $\mathrm{GH}$ administration, and $\mathrm{GH}$ withdrawal in trained adult males: a potential test for GH abuse in sport. J Clin Endocrinol Metab. 1999;84:3591-3601.

89. Wallace JD, Cuneo RC, Lundberg PA, et al. Responses of markers of bone and collagen turnover to exercise, growth hormone $(\mathrm{GH})$ administration, and GH withdrawal in trained adult males. J Clin Endocrinol Metab. 2000;85:124-133.
90. Erotokritou-Mulligan I, Basset EE, Cowan D, et al. The use of growth hormone $(\mathrm{GH})$-dependent markers in the detection of $\mathrm{GH}$ abuse in sport: physiological intra-individual variation of IGF-I, type 3 pro-collagen (P-III-P) and the GH-2000 detection score. Clin Endocrinol (Oxf). 2010;72:520-526.

91. Veitch SW, Findlay SC, Hamer AJ, Blumsohn A, Eastell R, Ingle BM. Changes in bone mass and bone turnover following tibial shaft fracture. Osteoporos Int. 2006;17:364-372.

92. Kurdy NM, Bowles S, Marsh DR, Davies A, France M. Serology of collagen types I and III in normal healing of tibial shaft fractures. J Orthop Trauma. 1998;12:122-126.

93. Bail HJ, Kolbeck S, Lindner T, et al. The effect of growth hormone on insulin-like growth factor I and bone metabolism in distraction osteogenesis. Growth Horm IGF Res. 2001;11:314-323.

94. Haukipuro K, Risteli L, Kairaluoma MI, Risteli J. Aminoterminal propeptide of type III procollagen in serum during wound healing in human beings. Surgery. 1990;107:381-388.

95. Erotokritou-Mulligan I, Bassett EE, Cowan D, et al. The influence of ethnicity on insulin like growth factor-I and procollagen III peptide in elite athletes and its effect on the ability to detect $\mathrm{GH}$ abuse. Clin Endocrinol (Oxf). 2009;70(1):161-168.

96. Bagg W, Aoina J, Cross PA, et al. Serum IGF-I levels are similar in Samoan, Maori and European populations despite differences in body composition. Growth Horm IGF Res. 2006;16:57-60.

97. Delellis K, Ingles S, Kolonel L, et al. IGF1 genotype, mean plasma level and breast cancer risk in the Hawaii/Los Angeles multiethnic cohort. Br J Cancer. 2003;88:277-282.

98. McGreevy K, Hoel B, Lipsitz S, Bissada N, Hoel D. Racial and anthropometric differences in plasma levels of insulin-like growth factor I and insulin-like growth factor binding protein-3. Urology. 2005;66:587-592.

99. Cuneo RC, Wallace JD, Sonksen P. Growth hormone abuse in elite athletes. In: Karch SB, editor. Drug abuse handbook. Boca Raton, FL: CRC Press; 2006.

100. Kniess A, Ziegler E, Kratzsch J, Thieme D, Muller RK. Potential parameters for the detection of hGH doping. Anal Bioanal Chem. 2003;376:696-700.

101. Chung L, Clifford D, Buckley M, Baxter RC. Novel biomarkers of human growth hormone action from serum proteomic profiling using protein chip mass spectrometry. J Clin Endocrinol Metab. 2006;91:671-677.

102. Goldhammer A. Regulatory implications for the use of pharmaceutical markers to improve the detection of human growth hormone. Drug Test Anal. 2009;1:439.

103. Haisma HJ, De Hon O, Sollie P, Vorstenbosch J. Gene doping. Netherlands Centre for Doping Affairs; 2004.

104. Kay MA, Manno CS, Ragni MV, et al. Evidence for gene transfer and expression of factor IX in haemophilia B patients treated with an AAV vector. Nat Genet. 2000;24:257-261.

105. The World Anti-Doping Agency. The World Anti-Doping Code-The 2006 Prohibited List International Standard. Available from: http:// www.olympic.org/Documents/Reports/EN/en_report_1019.pdf. Accessed June 07, 2011.

106. Sweeney HL. Gene doping. Sci Am. 2004;291:62-69.

107. Defrancesco L. The faking of champions. Nat Biotechnol. 2004;22: 1069-1071.

108. Unal M, Ozer UD. Gene doping in sports. Sports Med. 2004;34: 357-362.

\section{Dovepress}

\section{Publish your work in this journal}

Open Access Journal of Sports Medicine is an international, peer-reviewed, open access journal publishing original research, reports, reviews and commentaries on all areas of sports medicine. The manuscript management system is completely online and includes a very quick and fair peer-review system.
Visit http://www.dovepress.com/testimonials.php to read real quotes from published authors. 